\title{
Perempuan dan Tembakau di Mayang Kabupaten Jember: Perspektif Undang-Undang Nomor 13 Tahun 2003 tentang Ketenagakerjaan
}

\author{
Irham Bashori Hasba \\ Fakultas Syariah UIN Maulana Malik Ibrahim Malang \\ irbash@htn.uin-malang.ac.id \\ Dina Tsalist Wildana \\ Fakultas Hukum Universitas Jember \\ dinawildana@unej.ac.id
}

\begin{abstract}
:
This study addressed the issue of fulfillment of the rights of working women by Undang-Undang Nomor 13 Tahun 2003 Tentang Ketenagakerjaan. The approach taken in this study using the empirical sociology of law analysis and data collection using qualitative techniques such as observation and interviews. The results of this study indicate that women workers in the tobacco sector companies scattered in the district Mayang based analysis using the law number 13 of 2003 suggests that the absence of the right to women workers as set out in the legislation. But on the other, the company cannot be blamed entirely on the practice of considering the existence of an unwritten system where the job search process is set by the agent without providing and presenting a working agreement prior to workers. This happens because, according to the author because of the lack of knowledge that qualified for the women who work in the sector.

Penelitian ini membahas masalah pemenuhan hak perempuan yang bekerja menurut Undang-Undang Nomor 13 Tahun 2003 Tentang Ketenagakerjaan. Pendekatan yang dilakukan dalam penelitian ini bersifat empiris dengan menggunakan analisa sosiologi hukum dan pengumpulan datanya menggunakan teknik kualitatif berupa observasi dan wawancara. Penelitian ini menjelaskan bahwa pekerja perempuan di sektor perusahaan tembakau yang tersebar di Kecamatan Mayang berdasarkan analisa menggunakan Undang-Undang Nomor 13 Tahun 2003 Tentang Ketenagakerjaan menunjukkan bahwa tidak adanya pemenuhan hak atas pekerja perempuan sebagaimana tertuang dalam undangundang tersebut. Perempuan pekerja di sector ini tidak memperoleh jaminan kerja layaknya pekerja yang diatur dalam undang-undang. Namun disisi lainnya, perusahaan tidak dapat disalahkan sepenuhnya atas praktek tersebut mengingat adanya sebuah sistem tak tertulis dimana proses pencarian kerja diatur oleh agen yang tanpa memberikan dan menyuguhkan perjanjian kerja terlebih dahulu kepada pekerja. Hal tersebut terjadi karena menurut hemat penulis karena tidak adanya pengetahuan yang mumpuni bagi para perempuan yang bekerja di sector tersebut.
\end{abstract}

Kata Kunci: Pekerja Perempuan, Tembakau, UU Ketenagakerjaan

Bagian penting pembangunan nasional Indonesia adalah adanya sistem ketenagakerjaan. Pasal 27 Ayat 2 Undang-Undang Dasar 1945 mengamanatkan terciptanya ketenagakerjaan yang sehat dan berkelanjutan dengan jaminan sosial yang tinggi tanpa mendiskreditkan Jurisdictie: Jurnal Hukum dan Syariah Vol. 6 No. 2 Desember 2015 
siapapun, terlebih atas unsur sara. Penyelenggaraan pembangunan ketenagakerjaan merupakan manifest dari bergulirnya pembangunan nasional berdasar UUD 1945 bertujuan untuk membangun manusia Indonesia sehingga mampu mengangkat harga diri, harkat dan martabat seseorang sehingga dapat tercipta tatanan masyarakat yang adil, makmur, merata dan sejahtera bersama. ${ }^{1}$

Indikator keberhasilan pembangunan nasional dapat terlihat dari kualitas keberhasilan masyarakat Indonesia untuk maju dan adanya peningkatan jaminan kehidupan mereka berupa adanya pekerjaan dengan upah yang layak untuk menghidupi dirinya sendiri serta keluarganya. Hal tesebut sejalan dengan Pasal 27 Ayat 2 UUD 1945 yang menyatakan bahwa setiap warga negara berhak atas pekerjaan dan penghidupan yang layak.

Tenaga kerja berperan penting bagi keberhasilan pembangunan nasional sehingga Indonesia membuat pengaturan khusus bagi sistem ketenagakerjaan yaitu dikeluarkannya Undang-Undang Nomor 13 Tahun 2003 Tentang Ketenagakerjaan yang didalamnya mencakup perlindungan tenaga kerja sehingga sistem perlindungan ketenagakerjaan dapat menjamin hak-hak dasar para pekerja. ${ }^{2}$ Selain adanya sistem jaminan perlindungan bagi pekerja, mereka juga dituntut untuk berperan aktif dalam mengorganisir dan memperjuangkan haknya ketika terjadi ketimpangan dalam dunia kerjanya, salah satunya adalah aktif mengorganisir diri dalam organisasi serikat pekerja sehingga ketika diharuskan memperjuangkan ketimpangan mereka dengan melakukannya secara bersama-sama. ${ }^{3}$

Dalam Undang-Undang Nomor 13 Tahun 2003 Tentang Ketenagakerjaan menjelaskan tujuan adanya jaminan perlindungan bagi tenaga kerja adalah menjamin hak dasar pekerja dalam kesempatan yang sama dan tidak adanya perlakuan diskriminatif berdasar alasan apapun sehingga kesejahteraan pekerja dan keluarganya dapat terwujud dengan tetap melaksanakan tanggungjawab secara maksimal guna memajukan perusahaan dan dunia usahanya. ${ }^{4}$ Bekerja merupakan hajat hidup utama manusia. Seseorang akan mengharap dapat mencukupi kebutuhan jasmani dan rohaninya dengan cara bekerja dan memperoleh imbalan sesuai dengan pekerjaannya sehingga mereka dapat meningkatkan kualitas mutu hidup, status sosial dan kepuasan batin mereka. Seiring perkembangan jaman, akses terhadap pekerjaan dan pemenuhan kebutuhan rumah tangga tidak hanya digeluti oleh kaum laki-laki, namun juga dilakukan oleh kaum perempuan.

Dewasa ini, perempuan yang bekerja di berbagai sektor publik dan dunia kerja kian mudah dijumpai. Hal tersebut menunjukkan bahwa pola fikir yang menyiratkan adanya kesetaraan gender yang memposisikan perempuan dipandang mampu melakukan pekerjaan tertentu layaknya laki-laki sehingga mereka juga memiliki hak atas jaminan perlindungan sosial, ekonomi, dan lainnya meskipun secara kodrati perempuan dan laki-laki memiliki perbedaan secara biologis dan fisik sehingga dibutuhkan pengecualian tertentu terhadap perempuan yaitu ketika para pekerja perempuan tidak dapat menjalankan tugasnya dengan baik pada waktu tertentu.

Pemerintah melalui Undang-Undang Nomor 13 Tahun 2003 Tentang Ketenagakerjaan jelas memberikan garis damarkasi yang jelas terkait pengaturan dan perlindungan terhadap perempuan di perusahaan tempat bekerja. Pasal 81 UU No. 13 Tahun 2003 menerangkan bahwa seorang perempuan yang bekerja tidak diwajibkan bekerja jika sedang merasa sakit sebab haid pada hari pertama dan kedua, jika mereka mengkonsultasikan keluhannya kepada

\footnotetext{
${ }^{1}$ Hardijan Rusli, Hukum Ketenagakerjaan Bedasarkan UU No.13 Tahun 2003 Tentang Ketenagakerjaan Dan Peraturan Terkait Lainnya (Bogor: Ghalia Indonesia, 2011), 2.

${ }^{2}$ F.Winarni, Administrasi Gaji Dan Upah (Yogyakarta: Pustaka Widyatama, 2006), 89.

${ }^{3}$ Husni Lalu, Pengantar Hukum Ketenagakerjaan Indonesia, Edisi Revisi (Jakarta: PT Raja Grafindo Persada, 2000), 38 .

${ }^{4}$ Agusmindah, Hukum Ketenagakerjaan Indonesia Dinamika Kajian Dan Teori (Bogor: Ghalia Indonesia, 2010), 60 .
}

Jurisdictie: Jurnal Hukum dan Syariah Vol. 6 No. 2 Desember 2015 
atasan. Pasal tersebut menunjukkan bahwa perempuan memperoleh dispensasi karena faktor biologisnya. Pasal 82 UU No. 13 Tahun 2003 juga memberi dispensasi kepada perempuan untuk mengambil cuti kerja selama satu setengah bulan sebelum dan sesudah melahirkan, dengan catatan sesuai perhitungan dan rekomendasi dari dokter atau bidan yang menanganinya selama masa kehamilan. Sementara Pasal 83 UU No. 13 Tahun 2003 menyebutkan bahwa perempuan pekerja dapat beberapa kali istirahat bekerja untuk menyusui anaknya yang masih kecil. Sebagai lokasi penghasil dan pengolah bahan setengah matang produksi tembakau, Kecamatan Mayang merupakan salah satu kecamatan di Kabupaten Jember yang memiliki banyak perusahaan pengolah tembakau. Semua perusahaan tersebut mayoritas mempekerjakan perempuan sebagai buruh pengolah tembakau mentah menjadi produk setengah jadi yang siap dikirim ke perusahaan besarnya.

Pada konteks inilah penulis berusaha mencoba menganalisa terkait pekerja perempuan di beberapa perusahaan tembakau di Kecamatan Mayang Kabupaten Jember, khususnya terkait dengan pemenuhan hak mereka sebagai pekerja layaknya laki-laki dalam bingkai Undang-Undang Nomor 13 Tahun 2003 Tentang Ketenagakerjaan. Penelitian ini menggunakan metode penelitian empiris dengan kajian sosiologi hukum karena analisis yang digunakan adalah kondisi sosiologis perempuan yang bekerja di pabrik tembakau di Kecamatan Mayang dengan perspektif hukum yaitu analisa UU No. 13 Tahun 2003. Oleh karena itu, pendekatan yang digunakan adalah pendekatan sosiologi hukum. Pengambilan data menggunakan tipe observasi dan wawancara langsung dengan pekerja perempuan, disamping menggunakan pembanding data kepustakaan, khususnya terkait dengan perempuan dan ketenagakerjaan, dan kemudian data dianalisis dengan metode klarifikatif, verifikatif, konklusif dengan mekanisme analisis deskriptif.

\section{Kerangka Konsepsional}

Berbicara tentang pekerjaan dan ketenagakerjaan, tentu tidak lepas dari bagaimana pola dan kontrak yang dibangun antara perusahaan dan pekerjanya dalam perjanjian dan hubungan kerjanya. UU No. 13 Tahun 2003 Pasal 1 Point 15 memberi penjelasan bahwa ikatan kerja dibangun antara perusahaan dengan pekerja berdasar perjanjian kerja yang didalamnya terikat dengan unsur bentuk pekerjaannya, gaji dan tupoksi pekerjaannya. Sedangkan menurut Hartono, ikatan kerja terkait dengan pengerahan pekerja atau jasa seseorang yang berjalan terus menerus dengan tujuan untuk memperoleh pekerjaan, perintah dan upah atas seseorang. ${ }^{5}$

Hubungan kerja kedua belah pihak akan tercapai dan terjalin dengan baik jika kedua belah pihak saling menyepakati bersama dan mencatatkan kesepakatannya dalam sebuah catatan perjanjian kerja yang dibuat diawal sebelum pekerja memulai pekerjaannya. Mekanisme pembuatan perjanjian kerja sejatinya sederhana dan cukup dilakukan antara kedua belah pihak. Namun agar perjanjian tersebut dapat diakui secara legal, maka diperlukan proses pembuatannya yang dilakukan didepan para pihak dan disaksikan oleh notaris dan dibuat secara tertulis.

Menurut Soepomo, perjanjian kerja merupakan perjanjian yang mengikat seseorang untuk bekerja dengan menerima upah kepada pengusaha dan pengusaha terikat untuk memberikan upah atas pekerjaan para pekerjanya. ${ }^{6}$ Sementara Subekti menyebutkan bahwa perjanjian kerja antara pekerja dengan pemilik lapangan pekerjaan menimbulkan konsekuensi berupa diberikannya upah/gaji tertentu sebagai bahan perjanjian dan pemilik pekerjaan memperoleh hasil dari pekerjaan yang diperjanjikan, pengusaha berhak memberi perintah dan pekerja berkewajiban melaksanakannya. ${ }^{7}$

\footnotetext{
${ }^{5}$ Hartono dkk, Segi Hukum Penyelesaian Perselisihan Perburuhan (Jakarta: Rajawali Pers, 1992), 10.

${ }^{6}$ Soepomo Imam, Hukum Perburuhan Bagian Pertama Hubungan Kerja (Jakarta: PPAKRI Bhayangkara, 1968), 58.

${ }^{7}$ Subekti, Aneka Perjanjian, Cetakan Ke (Bandung: Penerbit Alumni, 1997), 63.

Jurisdictie: Jurnal Hukum dan Syariah Vol. 6 No. 2 Desember 2015
} 
Perjanjian Kerja dalam Pasal 1601 a Kitab Undang-Undang Hukum Perdata adalah sebuah kontrak antara para pihak yang saling mengikatkan diri, terdapat unsur memerintah dan menjalankan perintah, pemberi perintah mendapatkan hasil dari pekerjaan yang dilakukan dan penerima perintah memperoleh upah dari pekerjaannya. Perjanjian Kerja menurut Pasal 1 point 14 UU No. 13 Tahun 2003 adalah sebuah perjanjian yang dibuat oleh pekerja bersama pengusaha/pemberi kerja dengan memenuhi syarat kerja, hak dan kewajiban pengusaha/pemberi kerja dan pekerja.

Adanya pihak yang memerintah dan yang diperintah sebagaimana disebutkan diatas dengan tegas menunjukkan bahwa perjanjian kerja berbeda dengan perjanjian-perjanjian lainnya, dimana perjanjian kerja membentuk strukturasi yang jelas bahwa terdapat pihak penerima atau pelaksana perintah yang disebut buruh dan pihak pemberi perintah yang disebut majikan sehingga dalam perjanjian tersebut terdapat unsur terbentuknya wewenang yang harus sama-sama dilaksanakan dengan sebaik-baiknya oleh kedua belah pihak. ${ }^{8}$ Perjanjian kerja yang dibangun antara para pihak pada perjalanannya akan melahirkan pola baru yang saling memiliki keterkaitan antar keduanya. Pola tersebut kemudian disebut dengan hubungan kerja. Pasal 1 Point 15 UU No. 13 Tahun 2003 menyebutkan bahwa kontrak kerja terbentuk antara pekerja dengan perusahaan berlandaskan perjanjian kerja yang disepakati bersama dan dijalankan dengan sebaik-baiknya.

Abdul Rahman Budiono menyebutkan bahwa perjanjian kerja memiliki empat unsur penting yaitu: ${ }^{9}$ 1) Adanya Pekerjaan. Sesuatu yang dikerjakan merupakan hal penting terbentuknya perjanjian kerja. Seorang pengusaha dapat mengikat perjanjian kerja dengan buruhnya jika terdapat obyek yang dikerjakan. Tidak mungkin ada perjanjian kerja jika tidak ada yang dapat dikerjakan oleh seorang pekerja; 2) Upah, yaitu hasil dari pekerjaan seorang pekerja. Upah juga dapat bermakna hasil yang diharapkan seorang pengusaha dari apa yang dilakukan oleh pekerjanya. Jika sebuah pekerjaan tidak menjanjikan upah, niscaya perjanjian kerja antara kedua belah pihak tidak akan terjadi dan terlaksana dengan baik. Upah merupakan hak yang harus diberikan oleh pengusaha kepada pekerja sebagai kompensasi dari pekerjaannya, baik berupa uang atau lainnya sebagai imbalan dari pekerjaan yang dikerjakannya. Pemberian upah seyogyanya diatur dalam perjanjian kerja, sepanjang sistem pengupahan tidak bertentangan dengan undang-undang; 3) Pelayanan (Service). Sebuah pekerjaan jika dilakukan oleh pekerja dengan sungguh-sungguh dan dengan penuh kerelaan, maka akan memperoleh hasil yang maksimal bahkan lebih dari yang diharapkan. Hal tersebut pun akan berdampak pada kepuasan pengusaha atas hasil capaian pekerjaannya. Pola tersebut dapat dikategorikan sebagai sebuah pelayanan yang baik dari keduanya dan akan menghasilkan kepuasan masing-masing dan tidak menutup kemungkinan akan memperoleh bonus atau insentif lebih dari pelayanan yang diberikan dengan maksimal, berkualitas dan terbaik dari kedua belah pihak; 4) Waktu Pekerjaan (Timing) jelas dan ditentukan Hubungan kerja yang dibangun dan tertuang dalam perjanjian kerja harus menentukan waktu tertentu atas pelaksanaan pekerjaan dan disesuaikan dengan kesepakatan bersama dalam perjanjian kerja, serta sesuai dengan undang-undang. Dalam melakukan pekerjaannya, pekerja tidak boleh melakukan pekerjaan sesuai kehendak pengusahanya hidup. Hal tersebut penting digariskan dalam perjanjian kerja sebagai bentuk membangun komitmen bersama antar pihak dan tidak ada unsur menghilangkan hak kemanusiaannya dan tidak terbangun unsur perbudakan. ${ }^{10}$

Perjanjian kerja yang dibuat oleh pihak tertentu mengandung ketentuan dan syarat tertentu yang harus dipenuhi sehingga perjanjian tersebut akan disebut sah menurut hukum

\footnotetext{
${ }^{8}$ Djumadi, Hukum Perburuhan Perjanjian Kerja (Jakarta: PT.Raja Grafindo Persada, 1992), 31.

${ }^{9}$ Abdul Rahman Budiono, Hukum Perburuhan (Jakarta: PT. Indeks, 2009), 28.

${ }^{10}$ F.X. Djumialdji, Perjanjian Kerja, Cetakan IV (Jakarta: Bumi Aksara, 2001), 18.

Jurisdictie: Jurnal Hukum dan Syariah Vol. 6 No. 2 Desember 2015
} 
yang berlaku. ${ }^{11}$ Pasal 1320 Kitab Undang-Undang Hukum Perdata menyebutkan perjanjian kerja akan sah dengan syarat berupa: adanya kesepakatan antar para pihak, adanya kecakapan atas para pihak. Dalam konteks ini penulis memahami kecapakapan yaitu kecakapan pekerja adalah kemampuan pekerja dalam melaksanakan pekerjaan dan menjalankan perjanjian kerja, kecakapan pengusaha adalah kemampuan pengusaha untuk memberikan kompensasi berupa pengupahan dan insentif serta mampu melaksanakan perjanjian kerja, adanya hal tertentu dan sebab tertentu yang diperbolehkan menurut undang-undang.

UU No.13 Tahun 2003 Tentang Ketenagakerjaan Pasal 52 Ayat 1 menggariskan bahwa perjanjian kerja dibuat atas dasar: 1) Adanya kontrak kesepahaman antar kedua belah pihak. Pada konteks ini, kontrak yang dibuat merupakan bentuk perjanjian kerja yang harus disepakati atau disetuju oleh kedua belah pihak atas hal-hal yang dijadikan perjanjian; 2) Mampu melaksanakan kontrak yang terikat oleh hukum. Pada konteks ini, mampu dan cakap yang dimiliki para pihak yang membuat perjanjian dimaksudkan menurut hukum adalah adanya kemampuan untuk membuat dan melaksanakan perjanjian kerja dengan sebaikbaiknya. Sedangkan orang yang dinyatakan tidak layak membuat perjanjian dikategorikan sebagai: ${ }^{12}$ a) Belum dewasa dengan batasan usia belum genap 21 tahun dan atau belum kawin. Sementara UU No. 13 Tahun 2003 Pasal 1 angka 26 menyebutkan bahwa seorang dikategorikan cakap hukum ketika berusia 18 tahun; b) Orang dalam pengampunan yaitu orang dewasa yang gila, idiot, atau lemah akal; c) Orang yang boros; 3) Bentuk Pekerjaan. Pekerjaan yang menjadi obyek perjanjian dan disepakati para pihak melahirkan konsekuensi hukum berupa adanya hak dan kewajiban yang harus dilaksanakan oleh para pihak; 4) Tupoksi pekerjaan yang dijadikan bahan perjanjian dilarang bertentangan dengan ketertiban, kesusulaan, dan ketentuan peraturan perundang-undangan yang berlaku.

Pelaksanaan kontrak kerja memunculkan akibat hukum berupa keharusan untuk melaksanakan hak dan kewajiban yang dibuat dan disepakati bersama. Pasal 1603, 1603a, 1603 b dan 1603c Kitab Undang-Undang Hukum Perdata memberikan ketentuan terkait kewajiban pekerja berupa: 1) Wajib Bekerja. Bekerja merupakan tugas utama pekerja yang harus dilakukan sendiri dan tidak dapat diwakilkan karena terkait keahlianya. Ketika pekerja meninggal dunia maka kontrak kerja yang dibangun akan berakhir pula; 2) Pekerja harus mematuhi dan melaksanakan aturan dan petunjuk perusahaan atau pengusaha. Dibuatnya peraturan untuk pekerja berguna sebagai petunjuk bagi pekerja agar memahami dan melaksanakan pekerjaan sesuai tupoksinya; 3) Jika terdapat kerugian dan disebabkan kelalaian pekerja, dia wajib mengganti kerugian berupa denda atas tindakan lalainya. Jika pekerja melakukan tindakan yang dapat menyebabkan kerugian bagi perusahaan, baik tindakan tersebut disengaja atau karena kelalaian.

Sementara dari pihak pengusaha, kewajiban yang harus dipenuhi selain pengupahan dan pemberian bonus atas prestasi pekerjanya, juga berkewajiban untuk: 1) Kewajiban untuk berbuat sesuatu yang dianggap berguna bagi pekerja atau perusahaan dan atau tidak berbuat sesuatu yang dianggap tidak berguna dan akan menyebabkan kerugian bagi perusahaan atau pekerja. Seorang pengusaha harus harus bertindak atau tidak bertindak sesuai dengan ketentuan hukum yang berlaku dan harus mencegah sesuatu yang tidak baik dan dilarang menurut hokum; 2) Kewajiban untuk memberi istirahat tahunan. Kewajiban ini harus dilaksanakan oleh pengusaha dan perusahaan sesuai dengan ketentuan KUHPerdata Pasal 1602v jo PP Nomor 21 Tahun 1954 Tentang Istirahat Tahunan Buruh yang menyebutkan bahwa pengusaha diharuskan mengatur hak cuti atau istirahat secara teratur kepada pekerjanya; 3) Kewajiban mengurus perawatan dan pengobatan. Pasal 1602v KUHPerdata

\footnotetext{
11 "Lalu Husni," n.d.Lalu, Pengantar Hukum Ketenagakerjaan Indonesia, Edisi Revisi, 57.

${ }^{12}$ R. Soeroso, Perjanjian Dibawah Tangan Pedoman Praktis Pembuatan Dan Aplikasi Hukum (Jakarta: Sinar Grafika, 2010), 12.
}

Jurisdictie: Jurnal Hukum dan Syariah Vol. 6 No. 2 Desember 2015 
menyebutkan bahwa majikan atau pengusaha wajib mengurus perawantan dan pengobatan pekerjanya jika menderita sakit atau kecelakaan dalam jam kerja, dan dilaksanakan untuk 6 minggu pertama. Terkait hal ini, UU No. 3 Tahun 1992 Tentang Jamsostek telah mengatur perihal perlindungan bagi tenaga kerja yang sakit, kecelakaan, kematian telah dijamin melalui perlindungan Jamsostek; 4) Kewajiban memberi surat keterangan. Sebagaimana diatur dalam Pasal 1602 a ayat 1 dan 2 KUH Perdata, seorang pengusaha berkewajiban memberikan surat keterangan resmi kepada setiap pekerja yang didalamnya berisi bentuk pekerjaan, lama bekerja, dan hubungan antara pekerja dengan pengusaha atau perusahaan, jika pekerja menyatakan mengundurkan diri dengan sendiri atau diberhentikan secara hormat. Surat keterangan ini sebagai bentuk jaminan dan pengalaman bekerja jika pekerja nantinya akan pindah pekerjaan dan dibutuhkan oleh perusahaan yang diminatinya nanti; 5) Kewajiban majikan untuk memberlakukan sama antara pekerja pria dan perempuan. Seorang pengusaha tidak boleh membedakan pekerja laki-laki atau perempuan dalam pemberian kesempatan pendidikan guna memperkuat pengetahuan dan keahlian pekerja, syarat kerja, kenaikan pangkan, pemberhentian dan pemutusan hubungan kerja, dan pengupahan, pekerja yang sudah dan belum bekerja, baik laki-laki atau perempuan. Namun pengusaha harus memberikan pembedakan antara laki-laki dan perempuan dalam konteks kondisi kodrati laki-laki dan perempuan, seperti masalah haid, kehamilan, menyusui, kesehatan dan kesusilaannya; 6) Kewajiban membayar upah. Sarana utama pekerja dan keluarganya adalah diterimanya upah dan pengusaha wajib membayarkannya. Pasal 1602 KUH Perdata menjelaskan bahwa akibat langsung dari pelaksanaan perjanjian kerja adalah pembayaran upah oleh pengusaha yang tepat pada waktunya.

Undang-Undang Nomor 13 Tahun 2003 Tentang Ketenagakerjaan memberikan perhatian khusus terkait perjanjian kerja yang dibagi dalam dua kategori yaitu perjanjian kerja waktu tertentu yang diatur dalam Pasal 56 Ayat 1 dan perjanjian kerja waktu tidak tertentu yang diatur dalam Pasal 60. Perjanjian Kerja Waktu Tertentu adalah perjanjian kerja yang jangka waktu berlakunya ditentukan. Perjanjian ini berlaku bagi karyawan kontrak yang jika perjanjian kerjanya habis, maka terjadi pemutusan hubungan kerja (PHK) dan karyawan tersebut tidak mendapat kompensasi berupa uang pesangon, uang penghargaan masa kerja, uang penggantian hak, atau uang pisah. ${ }^{13}$ Bentuk pekerjaan ini berupa pekerjaan yang tidak dapat dilakukan secara terus menerus, tidak terputus dan dibatasi waktu, dan pengerjaan program atau proyek tertentu dalam sebuah perusahaan. ${ }^{14}$ Pasal 58 UU No. 13 Tahun 2003 menyebutkan bahwa perjanjian kerja waktu tertentu tidak diperkenankan memberikan syarat kepada pekerja berupa masa percobaan kerja. Jika perusahaan mencantumkan syarat tersebut maka dianggap tidak sah oleh hukum. Perjanjian Kerja Waktu Tidak Tertentu adalah kontrak kerja yang tidak mencantumkan waktu berlakunya, kebiasaan atau undang-undang. ${ }^{15}$ Surat perjanjian ini harus memuat nama dan alamat pekerja, tanggal dimulainya bekerja, jenis pekerjaan dan upah yang nanti akan diterima. ${ }^{16}$

\section{Pekerja Perempuan Menurut Undang-Undang Nomor 13 Tahun 2003}

Undang-Undang Nomor 13 Tahun 2003 Tentang Ketenagakerjaan secara jelas membedakan antara pekerja laki-laki dan perempuan dalam dunia kerja. Pembedaan tersebut didasarkan atas kondisi biologis, fisik dan psikis seorang perempuan dalam dunia perusahaan. Pasal 76 Undang-Undang Nomor 13 Tahun 2003 Tentang Ketenagakerjaan menjelaskan

\footnotetext{
${ }^{13}$ Jehani Libertus, Hak-Hak Pekerja Bila Di-PHK, Cetakan IV (Tanggerang: Visi Media, 2007), 5.

${ }^{14}$ Hardijan Rusli, Hukum Ketenagakerjaan Bedasarkan UU No.13 Tahun 2003 Tentang Ketenagakerjaan Dan Peraturan Terkait Lainnya, 66.

15 "Koko Kosidin, Perjanjian Kerja Perburuhan dan Peraturan Perusahaan" n.d., 28.

${ }^{16}$ Hardijan Rusli, Hukum Ketenagakerjaan Bedasarkan UU No.13 Tahun 2003 Tentang Ketenagakerjaan Dan Peraturan Terkait Lainnya, 70.
}

Jurisdictie: Jurnal Hukum dan Syariah Vol. 6 No. 2 Desember 2015 
tentang waktu dan pelayanan bagi pekerja perempuan yaitu: a) Perempuan yang berumur kurang dari 18 tahun tidak diperkenankan bekerja di perusahan pada jam 23.00 malam sampai pukul 07.00 pagi; b) Perempuan yang sedang hamil dilarang dipekerjakan pada jam 23.00 07.00 berdasar pada keterangan dokter yang menyatakan hal tersebut dapat membayakan kandungan atau dirinya; c) Perusahaan yang mempekerjakan wanita pada pukul $23.00-07.00$ pagi wajib memberi makanan dan minuman yang bergizi, menjaga keamanan dan kesusilaan selama berada ditempat kerja; d) Perusahaan wajib menyediakan angkutan antar jemput diwaktu antara pukul 23.00- 07.00 bagi perempuan.

Pasal 77 Undang-Undang Nomor 13 Tahun 2003 Tentang Ketenagakerjaan mengatur tentang penentuan waktu bekerja bagi pekerja perempuan sebagai berikut: 1) Perusahan wajib mengatur ketentuan waktu kerja bagi para pekerja, khususnya bagi pekerja perempuan; 2) Penentuan waktu kerja bagi pekerja perempuan dalam satu hari sebanyak 7 jam atau 6 hari kerja sebanyak 40 jam; 3) Bagi pekerjaan di sektor usaha atau pekerjaan tertentu, waktu kerja pekerja perempuan dalam satu hari berdurasi 8 jam, satu minggu dengan 6 hari kerja sebanyak 40 jam. Pasal 78 Undang-Undang Nomor 13 Tahun 2003 Tentang Ketenagakerjaan memberikan ketentuan bahwa: 1) Perusahaan yang mempekerjakan perempuan dengan durasi waktu melebihi $7-8$ jam sehari, 40 jam dalam satu minggu dengan masa kerja 6 hari harus memperoleh persetujuan dari pekerja yang bersangkutan; 2) Penentuan lembur kerja bagi perempuan durasi waktunya dalam satu hari maksimal 3 jam dan dalam satu minggu maksimal 14 jam; 3) Lembur pekerjaan harus diberi upah lembur diluar upah biasanya sebagaimana tertera dalam perjanjian kerja.

Pasal 79 Undang-Undang Nomor 13 Tahun 2003 Tentang Ketenagakerjaan memberikan ketentuan tentang waktu istirahat dan cuti berupa: 1) Jam istirahat dan cuti harus diberikan oleh perusahaan dengan ketentuan: a) Istirahat kerja selama setengah jam atas pekerjaan yang dilakukan selama 4 jam berturut-turut dalam satu harinya dan jam istirahat tidak terhitung jam kerja; b) Perusahaan wajib memberikan waktu istirahat dalam satu minggu sehari untuk 6 hari kerja atau dua hari untuk lima hari kerja; c) Dalam satu tahun, perusahaan wajib memberikan cuti tahunan minimal 12 hari setelah pekerja bekerja selama 12 bulan berturut-turut; d) Karyawan yang bekerja selama 6 tahun berturut-turut, perusahaan wajib memberi istirahat panjang selama 1 bulan pada tahun ketujuh dan 1 bulan pada tahun kedelapan pada satu perusahaan; 2) Penentuan istirahat tersebut hendaknya diatur dalam kontrak kerja dan peraturan tertulis perusahaan lainnya.

Pasal 81, 82, 83 dan 84 Undang-Undang Nomor 13 Tahun 2003 Tentang Ketenagakerjaan memberikan pengaturan terkait hak perempuan secara biologis, yaitu: 1) Perusahaan harus mengatur tentang pekerja perempuan yang merasa sakit karena sedang haid dan melaporkannya kepada perusahaan, diperbolehkan tidak bekerja pada hari pertama dan kedua masa haidnya; 2) Pekerja perempuan pada 1,5 bulan sebelum dan sesudah melahirkan berhak memperoleh waktu istirahat bekerja sesuai dengan keterangan dan perhitungan dari dokter atau bidan yang mengurusi kehamilannya; 3) Pekerja perempuan berhak memperoleh istirahat selama 1,5 bulan jika mengalami keguguran kehamilannya dengan melampirkan keterangan kesehatan dari dokter atau bidan yang menangani kandungannya; 4) Pekerja perempuan harus diberi kesempatan untuk menyusui anaknya ketika berada diwaktu dan lokasi kerja; 5) Perempuan pekerja yang sedang menjalani istirahat seperti tersebut diatas berhak menerima upah kerjanya secara normal.

\section{Hak Pekerja Perempuan di Pabrik Tembakau di Kecamatan Mayang dalam Perspektif UU No. 13 Tahun 2013}

Undang-Undang Nomor 13 Tahun 2003 Tentang Ketenagakerjaan yang mengatur tentang pekerja perempuan termaktub dalam pasal 76, 81, 82 dan 83. Namun dalam konteks penelitian ini, penulis tidak menyertakan analisis atas pasal 76 karena semua perusahaan Jurisdictie: Jurnal Hukum dan Syariah Vol. 6 No. 2 Desember 2015 
tembakau yang berada di kecamatan mayang kabupaten jember tidak memiliki ketentuan kerja pada jam malam. Implementasi terhadap hak pekerja perempuan di semua perusahaan pengolahan tembakau yang berada di kecamatan mayang kabupaten jember tidak terlaksana semua dengan baik. Perusahan tersebut tidak memenuhi amanat Pasal 81, 82, dan 83 UndangUndang Nomor 13 Tahun 2003 Tentang Ketenagakerjaan secara utuh dan hanya bagianbagian atau point-point tertentu saja yang dilaksanakan.

Aturan terkait pekerja perempuan yang sedang mengalami haid dan merasakan sakit tidak dicantumkan dalam aturan semua perusahaan, sehingga ketika ada pekerja perempuan yang merasakan hal tersebut dianjurkan untuk tidak masuk kerja dan dilakukan pemotongan penerimaan upahnya. Hal tersebut menunjukkan bahwa perusahaan tembakau yang mempekerjakan perempuan di wilayah kecamatan mayang tidak memperhatikan hal tersebut. Bahkan justru mewajibkan pekerja perempuan untuk tidak masuk kerja karena dikhawatirkan akan mengotori barang yang sedang di produksi. Keterangan terkait ini didapatkan oleh penulis setelah mewawancari hampir 50 orang pekerja perempuan yang berasal dari Dusun Tegalgusi Desa Mayang Kecamatan Mayang yang bekerja di setiap perusahaan yang berbedabeda dan hasilnya menunjukkan keterangan yang sama.

Aturan terkait pekerja perempuan yang sedang melahirkan juga sama dengan aturan tentang haid. Semua perusahaan tembakau yang berada diwilayah kecamatan mayang tidak memiliki aturan baku terkait mekanisme cuti atau istirahat bagi pekerja perempuan yang keguguran, hamil dan melahirkan. Dari keterangan 50 pekerja perempuan yang bekerja dan tersebar di semua perusahaan, tidak ada ketentuan dan aturan yang mengatur terkait istirahat kehamilan bagi pekerja perempuan. Jika terdapat perempuan yang hamil dan hendak melahirkan, mereka cenderung di rumahkan atau di berhentikan bekerja dan ketika mereka sudah benar-benar sehat dan siap untuk bekerja kembali ke perusahaan maka pihak perusahaan akan menerimanya kembali, sehingga pekerja perempuan tersebut tidak memperoleh hak yang semestinya diperoleh sesuai aturan yang berlaku yaitu Undang-Undang Nomor 13 Tahun 2003 Tentang Ketenagakerjaan.

Aturan terkait hak perempuan pekerja untuk menyusui juga memiliki nasib yang sama. Dari keterangan 50 perempuan yang bekerja disemua perusahaan tembakau yang tersebar di kecamatan mayang, tidak ada satupun perusahaan yang menerapkan aturan tentang pekerja perempuan yang sedang menyusui. Konsekuensi bagi perempuan yang sedang menyusui adalah dua pilihan yaitu berhenti bekerja sementara atau memberhentikan anaknya menyusui dan menggantinya dengan susu pabrikan. Aturan yang berlaku di setiap perusahaan tembakau yang tersebar di Kecamatan Mayang jika dikaitkan dengan implementasi Undang-Undang Nomor 13 Tahun 2003 Tentang Ketenagakerjaan hanya berupa diberikannya pesangon 1 kali gaji bagi perempuan yang ijin berhenti sementara dari bekerja karena melahirkan dan diberi kesempatan untuk kembali bekerja setelah benar-benar siap untuk kembali bekerja. Hal tersebut terjadi karena perusahaan mempekerjakan para pekerja perempuan sebagai pekerja dengan perjanjian kontrak atau perjanjian kerja tidak tertentu sehingga pekerja perempuan tidak memiliki ikatan yang tetap dengan perusahaan.

\section{Kesimpulan}

Berdasarkan pembahasan diatas terkait pekerja perempuan dan tembakau dapat disimpulkan bahwa pekerja perempuan di perusahan tembakau yang tersebar di Kecamatan Mayang tidak memperoleh haknya sesuai dengan Undang-Undang Nomor 13 Tahun 2003 Tentang Ketenagakerjaan sehingga secara normatif, perusahan-perusahan tersebut tidak melaksanakan isi Undang-Undang Nomor 13 Tahun 2003 Tentang Ketenagakerjaan. Pekerja Perempuan tidak memiliki kejelasan nasib di perusahaan tembakau dikarenakan mereka hanya menjadi pekerja dengan perjanjian kerja tidak diatur waktu. Bahkan ironisnya, mereka tidak pernah melakukan penandatanganan perjanjian kerja. Mereka bekerja hanya berdasar Jurisdictie: Jurnal Hukum dan Syariah Vol. 6 No. 2 Desember 2015 
pada ajakan agen yang mencari pekerja dan jaminan diakui sebagai pekerja di perusahaan tersebut dalam bentuk diberikannya kartu pekerja yang didalamnya tidak mencantumkan perjanjian kerjanya. Disisi yang lain, perusahaan tidak sepenuhnya dipersalahkan karena manajemen yang dibangun memang tanpa ada ikatan perjanjian kerjanya. Jika ingin melakukan evaluasi atas hal tersebut, maka langkah yang tepat adalah memperbaiki menejemen rekrutmen pekerjanya yang dilakukan oleh mandor yang bertugas mencari pekerja. Disamping memang perlu dibentuk serikat pekerja di setiap perusahaan tersebut.

\section{Daftar Pustaka}

Agusmindah. Hukum Ketenagakerjaan Indonesia Dinamika Kajian Dan Teori. Bogor: Ghalia Indonesia, 2010.

Budiono, Abdul Rahman. Hukum Perburuhan. Jakarta: PT. Indeks, 2009.

Djumadi. Hukum Perburuhan Perjanjian Kerja. Jakarta: PT.Raja Grafindo Persada, 1992.

F.Winarni. Administrasi Gaji Dan Upah. Yogyakarta: Pustaka Widyatama, 2006.

F.X. Djumialdji. Perjanjian Kerja. Cetakan IV. Jakarta: Bumi Aksara, 2001.

Hardijan Rusli. Hukum Ketenagakerjaan Bedasarkan UU No.13 Tahun 2003 Tentang Ketenagakerjaan Dan Peraturan Terkait Lainnya. Bogor: Ghalia Indonesia, 2011.

Hartono dkk. Segi Hukum Penyelesaian Perselisihan Perburuhan. Jakarta: Rajawali Pers, 1992.

Imam, Soepomo. Hukum Perburuhan Bagian Pertama Hubungan Kerja. Jakarta: PPAKRI Bhayangkara, 1968.

Lalu, Husni. Pengantar Hukum Ketenagakerjaan Indonesia, Edisi Revisi. Jakarta: PT Raja Grafindo Persada, 2000.

Libertus, Jehani. Hak-Hak Pekerja Bila Di-PHK. Cetakan IV. Tanggerang: Visi Media, 2007.

R. Soeroso. Perjanjian Dibawah Tangan Pedoman Praktis Pembuatan Dan Aplikasi Hukum. Jakarta: Sinar Grafika, 2010.

Subekti. Aneka Perjanjian. Cetakan Ke. Bandung: Penerbit Alumni, 1997. 